\title{
Fabricating and Governing the Swedish School Pupil: The Swedish Post-War School Reform and Changing Discourses of Discipline and Behaviour
}

\author{
Jonas Qvarsebo
}

\begin{abstract}
This article examines the dominant discourses of behaviour and discipline in the debate on schooling and the conduct of school pupils in Swedish professional teacher journals between 1946 and 1962, the formative years of the Swedish comprehensive school. Drawing from the theoretical framework of discourse, governmentality and the fabrication of the subject developed by Michel Foucault, the fabrication and governing of the school pupil is highlighted and analysed. The findings of the study are related to historical research of the period as well as Foucauldian studies where a historical shift of perspectives on discipline and behaviour in the school have been proposed. The result is a detailed analysis of the fabrication and governing of the subject within the dominant discourses of behaviour and discipline during the period, as well as a critical nuancing of the idea of this historical shift.
\end{abstract}

Keywords • educational history, governmentality, discourse, subject, childhood and youth

\section{Introduction}

The difficult child has long been, and still is, the ugly duckling in our educational system. Blind, deaf-mute and intellectually retarded children have received better care and education than difficult children, even although much remains to be done for children in these categories. ${ }^{1}$

These words introduced an article by elementary school teacher Axel Norén on the role of the Swedish educational system in educating and disciplining the nation's children. The article was published in the professional periodical Svensk Lärartidning (Swedish Teachers' Journal) in 1949. The role of public schooling in children's upbringing, especially in relation to the "difficult child," was a hot issue in the Swedish educational debate between the 1940s and 1960s. Educators spoke of "a crisis in education" and laments about "the disintegration of discipline" and "a lack of norms" were often heard. ${ }^{2}$ In this article I explore the dominant discourses of behaviour and discipline that surfaced in this debate, highlighting the fabrication and governing of

An earlier version of this article has been published in Swedish with the title "Det önskvärda skolbarnet: Diskurser om barn och fostran i Svensk Lärartidning 1946-1962," in Normalitetens förhandling och förvandling: En antologi om barn, skola och föräldraskap, ed. Judith Lind (Lund: Symposium, 2006). The anthology is now out of print and the text has been reworked from a Foucauldian governmentality perspective.

1 Svensk Lärartidning 2 (1949), 40, my translation.

2 Lennart Husén and Nils-Eric Svensson, Elever - lärare - föräldrar: En studie av skolans uppfostringsoch disciplinproblem (Stockholm: Almqvist \& Wiksell, 1959), 15ff.

Jonas Qvarsebo is a Senior Lecturer in Educational Science at the Faculty of Education and Society, Malmö University, Sweden.

Email: jonas.qvarsebo@mau.se

Nordic Journal of Educational History 2018. @ Jonas Qvarsebo. This is an Open Access article distributed under the terms of the Creative Commons CC-BY4.0 License (http://creativecommons.org/licenses/by/4.0/). 
the school pupil within these discourses. I am specifically interested in the various fabrications of the desirable school pupil and its counterpart, the difficult or bad school pupil, together with the rationality and logics of governing at play in these discourses, and how the discourses were legitimised. By analysing the discourses at play in the debate, I seek to problematise and nuance the idea of a historical shift of behaviour and discipline during the period. ${ }^{3}$

The starting point for this study is that schooling has played, and still plays, an important role in the production of discourses of behaviour and discipline in relation to children and youth. With the introduction of public schooling in the nineteenth century, children began to emerge as a separate segment of the population, distinct from adults. This brought children into an arena where they could be observed, classified and moulded in different ways. ${ }^{4}$ Public schooling has thus played an important role in making possible notions of "the child," "childhood" and "the pupil" as fields of knowledge and domains of government. ${ }^{5}$ In commenting on the many ways in which children began to be observed and governed from the twentieth century on, Nikolas Rose has gone so far as to say that "childhood is the most intensely governed sector of personal existence." While schooling has been instrumental in shaping notions of childhood and the way children's lives have been governed for a long time, the scientification of children and childhood from the late nineteenth and early twentieth century on was instrumental in making childhood into a more uniform concept than in earlier times. ${ }^{7}$ The Swedish school reform period from the 1940s to the 1960 s played an important role in this process as the field of pedagogics began to merge with new psychological discourses of development and behaviour. During this period, older and traditional forms of discipline were challenged by progressive ideas of childrearing and discipline, resulting in a struggle over how best to govern the school pupil. ${ }^{8}$

Several influential Swedish historical studies on schooling, discipline and behav-

3 I have made an attempt at problematising and nuancing this process in another study that covers the same time period, see Jonas Qvarsebo, "Swedish progressive school politics and the disciplinary regime of the school, 1946-1962: A genealogical perspective," Paedagogica Historica 49, no. 2 (2013), 217-35. In that article I drew attention to a type of political history writing that assumes a radical democratic transition of society during this period, with the older regime of discipline in schools being replaced by a democratic and humanitarian discourse. Drawing on Foucault's genealogical method, I questioned this history writing and suggested that the process could instead be viewed as a widening and deepening of disciplinary practices, but by new methods. In this article, the emphasis is on the fabrication of the subject in the debate on schooling, discipline and behaviour during the period, rather than the wider school political process.

4 See Nikolas Rose, Governing the Soul: The Shaping of the Private Self (London: Free Association Books, 1999); Andrè Turmel, A Historical Sociology of Childhood: Developmental Thinking, Categorization and Graphic Visualization (Cambridge: Cambridge University Press, 2008); Jonas Qvarsebo, Skolbarnets fostran: Enhetsskolan, agan och politiken om barnet (Linköping: Linköpings universitet, 2006).

5 See Bernadette Baker, "Childhood-as-rescue in the emergence and spread of the U.S. public school," in Foucault's Challenge: Discourse, Knowledge and Power in Education, ed. Thomas Popkewitz and Marie Brennan, (New York Teachers College Press, 1999), 117-143; Kenneth Hultqvist and Gunilla Dahlberg, eds., Governing the Child in the New Millenium (New York: RoutledgeFalmer, 2001); Harry Hendrick, Children, Childhood and English Society 1880-1990, New Studies in Economic and Social History (Cambridge: Cambridge University Press, 1997); Qvarsebo (2006).

6 Rose (1999), 123.

7 See Rose (1999); Qvarsebo (2006).

8 See Qvarsebo (2006); Qvarsebo (2013). 
iour speak of a major shift of perspective during the twentieth century, with the 1940s and 1950s as the watershed years. Special emphasis has been placed on the shift from a moral to a psychological-scientific discourse of behaviour and conduct. This has been described in quite dramatic terms as "a real breakthrough for a new outlook on children and their development." 9 The shift is described as particularly dramatic when it comes to changed notions of the difficult child, from being viewed as morally bad to psychologically defective or deviant, resulting in a change from disciplinary measures such as physical punishment to democratic methods of dialogue and participation. This claim has been made in several traditional works on educational history as well as in Foucauldian inspired studies, and has become inscribed in contemporary political discourses on the progress of society. Even if this narrative of progress and humanisation has been questioned by many scholars working within more critical frameworks, the notion of the past as dark and gloomy and the present as bright and enlightened still lingers on in both research and political discourse. ${ }^{10}$ In Foucauldian studies there has been a tendency to describe the governing of the child in terms of a discursive transition of power relations, a shift from a governing from without to a governing from within-from disciplining the body to normalising the soul. This has been interpreted as a transition from one rationality of governing to another, from disciplinary power working through regulations and physical punishment to normalising power working through therapeutic techniques. ${ }^{11}$ The psychological sciences have been ascribed a major role in this shift. Psychology is assumed to have provided this form of governing with new forms of knowledge of human behaviour and the self, thus making the development of new technologies and techniques of governing possible. The process has also been described in terms of a neo-liberal rationality of governing, where the subject has become a co-actor in its own government, a governing of the self in the name of freedom and democracy. ${ }^{12}$

9 Gunnar Richardson, Drömmen om en ny skola: Ideer och realiteter i svensk skolpolitik 1945-1950 (Stockholm: Liber Förlag, 1983), 91.

10 For the traditional historical version of this narrative of progress, see Richardson (1983); Sixten Marklund, Skolsverige 1950-1975. Volym 4: Differentieringsfrågan (Stockholm: Liber/utbildningsförlag, 1985). In newer historical studies this progressive narrative is often problematised, but there is still a tendency to locate disciplinary techniques in the past and discuss the present in terms of humanitarianism and democracy, while not commenting on the disciplinary aspects of the present, see for instance Henrik Edgren, "Folkskolan och grundskolan," in Utbildningshistoria, ed. Esbjörn Larsson and Johannes Westberg (Lund: Studentlitteratur, 2015). For a Swedish Foucauldian inspired variant of this history writing, see Bengt Börjesson, "Det ideologiskt omstridda barnet," in Seendet och seendets villkor: En bok om barns och ungas välfärd, ed. Lars Dahlgren and Kenneth Hultqvist (Stockholm: HLS, 1995). There is also a body of work within Foucauldian studies where this narrative of humanitarian enlightenment is more consistently questioned and where the present is problematised in relation to disciplinary methods of various kinds-see for instance Stephen Ball, Foucault, Power and Education (New York: Routledge, 2013). See also Qvarsebo (2013).

11 The starting point for these descriptions of the historical shift of power is usually Foucault's study of the origins of prison, Michel Foucault, Discipline and Punish: The Birth of the Prison (London: Penguin, 1978). For an influential Foucauldian study of a transition from governing the body of the child to normalising the soul through psychological techniques, see Nikolas Rose's "The Gaze of the Psychologist" in Rose (1999).

12 The importance of psychological knowledge in this process has been described by Nikolas Rose among others. See Nikolas Rose, The Psychological Complex: Psychology, Politics and Society in England 1869-1939 (London: Routledge, 1985). For a similar view by a Swedish Foucauldian scholar, see Kenneth Hultqvist, Förskolebarnet: En konstruktion för gemenskapen och den individuella frigörelsen - En nutidshistorisk studie om makt och kunskap i bilden av barnet i statliga utredningar om förskolan (Stockholm: Symposium, 1990). 
This article is arranged as follows: A brief introduction is devoted to the history and background of Swedish comprehensive school reform and the debate on behaviour and discipline between 1946 and 1962. Next is a discussion of the article's theoretical perspective, analytical tools and areas of inquiry. A brief description of the source material and methodology then precedes the actual analysis of the debate on behaviour and discipline in school. Finally, the findings of the study are discussed against the background of previous research on the school, discipline, behaviour and childhood during the period.

\section{A unified school system and conflicting discourses of discipline}

After the Second World War, the vision of a comprehensive school system for all the nation's children definitively asserted itself in Swedish educational politics. The older system of parallel schools with several forms of elementary school and secondary school was now to be superseded by a unified and compulsory comprehensive school system for all children. The complex issue of how best to achieve this, and how to resolve related problems and challenges, had long been the crux of Swedish educational politics. ${ }^{13}$ Against the backdrop of two major schools commissions, the 1940 Schools Commission (1940 års skolutredning) and the 1946 Schools Commission (1946 års skolkommission), the parliament (Riksdag) of 1950 passed a resolution of principle for the introduction of nine-year compulsory comprehensive schooling. The final decision was preceded by a twelve-year period of testing, after which the 1962 Riksdag passed the nation's first education act for comprehensive schooling, stipulating that a nine-year comprehensive school system was to be successively introduced throughout the nation. ${ }^{14}$

The vision of a common school system for all children was part of the grand postwar political vision of a thoroughgoing democratisation of all sectors of society. The democratisation efforts also permeated the debate on education and resulted in a major shift of educational goals and objectives. The 1940 Schools Commission had stressed the importance of continuing to build on an intrinsically Swedish tradition of education and culture. The time of war had made possible an emphasis on concepts such as folk and nation as embracing the entire population and extending into the school sphere. By contrast, the commission of 1946 emphasised concepts such as democracy, independence and individual freedom rather than collective and nationalistic ideals. ${ }^{15}$ In its final report, the commission claimed that the school system had not kept up with developments in society. What was needed was more than just a rapid advance in the teaching of science and technology; the goal was a complete break with older, authoritarian practices and the establishment of modern, democratic practices. This shift was thought to require in-depth reforms of all societal in-

13 See Qvarsebo (2006); Jonas Qvarsebo, "Grundskolereformen och talet om differentieringen: Differentieringsfrågan och konstruktionen av barns och ungas olikheter," in Historien, barnen och barndomarna: Vad är problemet? ed. Judith Lind et al. (Linköping: Linköpings Universitet, 2009); Thom Axelsson, Rätt elev i rätt klass: Skola, begåvning och styrning 1910-1950 (Linköping: Linköpings Universitet, 2007).

14 For an in-depth description and analysis of this process, see Richardson (1983) and Qvarsebo (2006).

15 SOU 1948:27, 1946 års skolkommissions betänkande med förslag till riktlinjer för det svenska skolväsendets utveckling, $2 \mathrm{ff}$. 
stitutions, including the educational system. The commission viewed its guidelines as a major contribution to the nationwide democratisation of society. ${ }^{16}$

The democratisation of the school system meant first and foremost that all children should receive an equal education and be equipped for democratic citizenship. In the parallel school system, gender, class, geography and intellectual ability had been the main differentiating factors. The amalgamation of the old school forms into one comprehensive school system meant that these differentiations could be done away with, and a system built on democracy and equality could be realised. In conjunction with this process, a controversy about discipline in school arose. The political vision to integrate the educational system came into conflict with disciplinary practices that had existed within the parallel school system. This was most noticeable when it came to the practice of corporal punishment. In preparatory schools such punishment had long been banned, and in girls' schools it had never been introduced.${ }^{17}$ However, in elementary schools, which served the majority of children, corporal punishment was permitted in certain circumstances, namely, "if the child did not show improvement through any other correctional means." ${ }^{18}$ As the comprehensive school reform began to be implemented, the different forms of discipline became visible and could be constructed as a social problem that needed to be managed, making new discourses of shaping behaviour and attitudes possible. ${ }^{19}$

\section{Discourse, governmentality and the subject}

The debate on discipline and behaviour in school will be explored in this article using some key concepts from Michel Foucault's "toolbox." ${ }^{20}$ I will especially make use of the concepts of discourse, governmentality and power/knowledge and how these relate to the fabrication and governing of the subject. In The Archaeology of Knowledge, Foucault defines discourse as "practices that systematically form the objects of which they speak." ${ }^{21}$ From this perspective, discourse is more than words and ideas and does not merely describe or portray the world; it constitutes the world in specific ways, making it both thinkable and governable. Through specific forms of systematic and context-bound language, truths about the world-objects as well as subjects - are formed and put into play in various ways. Discourse is thus, by this definition, a way of organising knowledge that structures the perception of the world and of ourselves and how we think and act. How this understanding of discourse can be turned into method will be discussed in relation to the discussion of sources and methodology below.

This definition of discourse is intimately related to practices of power. Foucault, in his later works, coined the term governmentality to theorise and analyse the logics

\footnotetext{
16 SOU 1948:27.

17 Corporal punishment was banned in secondary schools in 1928.

18 Folkskolestadgan (regulations for the elementary school) \$29 (4), my translation.

19 See Qvarsebo (2006); Qvarsebo (2013).

20 Foucault explicitly called his work "A kind of toolbox," Michel Foucault, "Prisons et asiles dans le mécanisme du pouvoir," in Dits et Ecrits, t. II (Paris: Gallimard, 1994), 523-24.

21 Michel Foucault, The Archaeology of Knowledge and the Discourse on Language (New York: Pantheon Books, 1972).
} 
and mechanisms of practices of power in its many historical guises. ${ }^{22}$ The governmentality perspective on power in relationship to the state, civil society and the individual opens up an analysis of the ways people are governed that is not necessarily based on the formal exercise of power such as legislation and politics. Rather, from a governmentality perspective, power is viewed as relational, embedded in discourse and operating in the interplay between politics, science, culture and individual practices. $^{23}$ This perspective also opens up an analysis of how the human subject is shaped and formed, or fabricated, through discursive practices, which is what is highlighted in this article. In Foucault's work, the term "the subject" is used in a double sense; first, in the sense of personhood or identity, and second, in the sense of being subject to something or someone and thereby entangled in relationships of power where the truth of the subject is negotiated and fabricated. This understanding of the subject makes possible an analysis where the subject is freed from notions of essence and can be historicised and studied as a phenomenon in change. ${ }^{24}$

Thus, rather than starting a priori with an autonomous, self-reflexive (or Cartesian) subject, Foucault brings attention to the specific historic points in time where the subject and subjectivity are fabricated through discourse. ${ }^{25}$ This turns the subject and subjectivity into objects of empirical analysis rather than taken-for-granted starting points. To analyse the fabrication of the subject in this sense means that one does not try to understand the subject "as it is" but as it emerges in relation to the historically contingent forms of knowledge that have been allowed to describe and define the subject in various contexts. ${ }^{26}$ The history of the subject presumes, according to Foucault, two essential conditions: "a particular kind of knowledge and particular forms of power relations." ${ }^{27}$ Foucault therefore preferred to talk about the exercise of power and power relations rather than about power per se:

Power is not something that is acquired, seized, or shared, something that one holds on to or allows to slip away; power is exercised from innumerable quarters in the interplay of nonegalitarian and mobile relations. ${ }^{28}$

22 The governmentality concept is only briefly discussed by Foucault himself, see Michel Foucault, "Governmentality", in The Foucault Effect: Studies in Governmentality, ed. Graham Burchell, Colin Gordon and Peter Miller (Chicago: University of Chicago Press, 1991). The concept has been further developed by scholars such as Mitchell Dean, Nikolas Rose, Barbara Cruikshank and Ian Hunter. See, for instance Mitchell Dean, Governmentality: Power and Rule in Modern Society (Thousand Oaks: SAGE, 1999); Rose (1999); Barbara Cruikshank, The Will to Empower: Democratic Citizens and other Subjects (Ithaca: Cornell University Press, 1999); Ian Hunter, Rethinking the School: Subjectivity, Bureaucracy, Criticism (Sydney: Allen \& Unwin, 1994).

23 See Thom Axelsson and Jonas Qvarsebo, Maktens skepnader och effekter: Maktanalys i Foucaults anda (Lund: Studentlitteratur, 2017).

24 See Cruikshank (1999); Tina Besley and Michael Peters, Subjectivity and Truth: Foucault, Education and the Culture of Self (New York: Peter Lang, 2007).

25 See Sara Mills, Discourse (London: Routledge, 1997).

26 See Hubert Dreyfus and Paul Rabinow, Michel Foucault: Beyond Structuralism and Hermeneutics (Chicago: University of Chicago Press, 1982); Thomas Popkewitz, "The sociology of education as the history of the present: fabrication, difference and abjection," Discourse: Studies in the Cultural Politics of Education 34, no. 3 (2013), 439-56.

27 Sven-Åke Lindgren, "Michel Foucault och sanningens historia," in Moderna samhällsteorier ed. Per Månsson, (Stockholm: Rabén Prisma 1995), 328, my translation.

28 Michel Foucault, The History of Sexuality: An Introduction, vol. I (New York: Vintage Books, 1978), 94. 
Accordingly, power for Foucault is not something that an individual or group can have or own-like a thing or a substance-rather, power is viewed as relational and permeates all social relationships. Foucault's type of power analysis has been called an analytics of government, meaning that instead of focusing on traditional issues of power as hierarchy, structures and the powerful versus the powerless, it seeks to reveal patterns and codes of the power that permeates all human relations. ${ }^{29}$ In relation to the fabrication and governing of the human subject, Foucault stressed the intimate relationship between power and knowledge. This relationship is viewed as productive and as establishing specific, context-bound "regimes of truth" wherein the human subject is fabricated and made governable by various techniques of power. ${ }^{30}$ Thus, Foucault rejected the more general notion of power and knowledge where power is viewed as something made possible by knowledge. Rather, for Foucault, power and knowledge presuppose one another, and together they produce context-bound truths about the subject; hence his forging of power and knowledge into the combination power/knowledge.

Foucault was especially interested in the knowledge/power relations made possible within the human sciences such as sociology, pedagogy, anthropology, medicine, psychiatry, psychology and criminology. In various studies he investigated the discursive power-knowledge interplay within these disciplines and how subjectivities that can be managed and governed in certain ways are produced. Viewed from this perspective, a discipline such as criminology can be said to produce, or fabricate, "the criminal," psychology produces "the psyche" and "the psychologically ill," and psychiatry produces "the mentally ill," to mention a few examples. ${ }^{31}$ Embedded in these fabrications of the subject are certain notions of who is normal and abnormal and what is desirable and undesirable conduct, together with various techniques and strategies for protecting society from certain people through the accommodation, rehabilitation, curing or reforming of those who have been identified as deviants, abnormal or unproductive. The school, together with institutions such as the prison, the hospital and the factory, is one of the institutions where numerous techniques of governing and normalising are at work, and where the subject is shaped and formed in various ways. ${ }^{32}$

\section{Sources and methodological steps of analysis}

The material studied in this article is extracted from the professional periodical Svensk Lärartidning (Swedish Teachers' Journal). ${ }^{33}$ This journal existed between 1882 and 1963 under different names: Svensk Läraretidning (1882-1932), Svensk

29 Dean (1999).

30 Foucault (1978), 23, 30; Michel Foucault, “The political function of the intellectual," Radical Philosophy 17 no. 13 (1977), 126-33.

31 See Besley and Peters (2007).

32 Foucault (1978); Joseph Piro, "Foucault and the architecture of surveillance: creating regimes of power in schools, shrines, and society," in Educational Studies 44, no. 1 (2008), 33-46; Qvarsebo (2006); Joakim Landahl, Auktoritet och ansvar: Lärares fostrans- och omsorgsarbete $i$ historisk belysning (Stockholm: Stockholms Universitet, 2006); Axelsson (2007).

33 In addition to the journal, I drew on Joachim Israel and Mirjam Valentin Israel's book Det finns inga elaka barn (There are no mean children) from 1946 for the analysis of the progressive discourse. The book is used to enrich the understanding of Joachim Israel's articles in the journal and is presented and discussed in the analysis of progressive discourse. 
Lärartidning (1933-46), Folkskolan - Svensk Lärartidning (1947-56) and Folkskolan (1957-63). ${ }^{34}$ For the sake of simplicity, I will refer to the journal as the Swedish Teachers' Journal throughout this article, referencing the actual journal titles in the footnotes. This journal was the most important arena for discussion and debate for elementary school teachers during the period and is thus an interesting source for analysing discussions on topics of importance to teachers, including discipline and behaviour. I have selected articles where character, discipline and behaviour in relation to schooling were discussed in the journal between 1946 and 1962. In view of the many texts in which these themes are discussed, I have narrowed the material down to main articles, editorials and debates. This means that I have left out reviews, letters to the editor and similar minor texts. The articles used should be viewed merely as examples of dominant ways of talking about these issues during the period. ${ }^{35}$

A Foucauldian way of doing discourse analysis is not based on a method in the strict sense; rather, it is a way of posing questions to the material based on the understanding of discourse, power and the subject that has been outlined above. For this article, this means that I have focused attention on the forms of knowledge invoked in the discussion of discipline and behaviour pertaining to the school in the journal, the methods and techniques that were suggested, and the subjects that were fabricated through this discussion. More specifically, I have read the material while asking questions such as the following: What is being represented here as a truth or as a norm? How are this and that constructed? What "evidence" is used? What is made problematic and what is not? What alternative meanings or explanations are ignored? What is kept apart and what is joined together? What identities, actions, practices are made possible and/or desirable and/or required by this way of thinking/talking/understanding? Reading the articles with these kinds of questions in mind has led to the emergence of various themes pertaining to dominant discourses of behaviour and discipline, which I will discuss in detail below.

\section{The discipline discourse and the citizen discourse: The bad and the respon- sible school pupil}

In 1946, the Swedish Teachers' Journal published an article by headmaster Leander Wallerius entitled "Reward and Punishment." ${ }^{36}$ The article was a contribution to the emerging discussion on discipline and behaviour in schools at the time, where traditional methods of correction were being challenged by a new and progressive view on childrearing, related also to the school. The new and progressive ideas were criticised by Wallerius and others like him for being an attempt to frame undesirable behaviour as illnesses, medical or psychological, rather than as morally bad behaviour. Turning to the fabrication of the subject, the type of disciplinary pedagogics that these debaters advocated was partly made possible by a notion of the pupils as an anonymous collective that needed order and structure. There is a tendency in

34 Martin Widén, "Skoltidningar och tidskrifter," in Svenska folkskolans historia, Sjätte delen: Skolutvecklingen 1942-1962: Grundskolans förhistoria ed. Viktor Fredriksson (Stockholm: Stiftelsen för förvaltningen av Sveriges Allmänna Folkskollärarföreningstillgångar, 1971).

35 For a more substantial discussion of this source material and its role in the "politics of the child" during this period, see Qvarsebo (2006), 42-45. See also Landahl (2006), 25, for a discussion of the analytical value of this journal.

36 Svensk Lärartidning 50 (1946). 
several articles from this side of the debate to treat school pupils as a group and tone down all notions of individuality and personality. For instance, Wallerius frequently employed terms such as "clientele" and "the child material" when referring to pupils. The disciplinary problems of the school were said to be caused by "oversized classes with a mixed clientele," and a school pupil who showed some sort of undesirable behaviours or attitudes could be described as an "undisciplined element." ${ }^{37}$

This type of language was used for school pupils as a collective and as individuals. It served to objectify pupils by portraying them as things to be administered and managed through various disciplinary techniques. In its purest form, this was a form of power that was exercised on a subject whose body and habits could be governed and regulated without taking into consideration any personal or individual qualities such as intellect, will and emotions. The objectifying language also corresponded to a notion of discipline where the act of punishing could be described without taking any personal dimensions into consideration:

Immediate punishment thus appears as a biological necessity, just as overeating sweets will lead to a stomach ache, or venturing onto thin ice will cause drowning, and so forth. In brief, transgression calls forth its own punishment (my translation). ${ }^{38}$

The urgency of the act of punishment - as a "natural consequence" of undesirable behaviour - is here described as an impersonal law or a neutral effect, triggered by inappropriate behaviour. Such instrumental and mechanical descriptions of disciplinary practices portray both teachers and pupils as entities without intentions and emotions, or as actors playing the roles of the chastiser and the chastised within the framework of a system of discipline.

The same authors also described the administration of punishments for the bad school pupil as necessary measures to counter improper upbringing. As one commentator put it: "Unfortunately an educator is sometimes put in the position of having to administer discipline in one form or another." ${ }^{39}$ As this quotation suggests, one of the functions of corporal punishment was to maintain order in the school. Editor-in-chief Tore Stigbrand contributed an article where he sought understanding for the use of corporal punishment by pointing out situations where nothing else seemed to help when it came to maintaining order:

Elementary schoolteachers want to know how they should deal with a pupil who uses a slingshot to break all the street lamps that happen to be in his path, who uses his knife to carve his name in the doors of the school, a boy who conducts himself improperly toward his female classmates (my translation). ${ }^{40}$

In other words, if a school was to function satisfactorily, many different disciplinary measures must be available to teachers, including physical punishment.

The same authors who stressed the need for various kinds of disciplinary measures could also mobilise a citizenship discourse in which a somewhat different sub-

37 Ibid.

38 Ibid.

39 Ibid.

40 Ibid. 
ject emerges. The school should not only discipline and punish, it should also prepare the child for future citizenship. The above-mentioned Wallerius listed a number of qualities that a school pupil must acquire to become a good citizen: "obedience, punctuality, respect, courtesy, orderliness and attentiveness, industry and conscientiousness." ${ }^{11}$ These are moral qualities that cannot be formed in the pupils without their active participation. Hence, Wallerius stressed the need for school pupils to internalise these virtues through training both at home and in school: "A duty to exercise good behaviour is the foundation for good conduct; the home and the school are small-scale communities where good behaviour can be practised." ${ }^{\prime 2}$ In this quotation the school pupil is portrayed as a social actor who, within both the home and the school, is expected to train to become a model citizen. The type of governing that surfaces in these descriptions is thus not only about coercion; rather, it involves a combination of coercion and free participation. The discipline discourse and the citizenship discourse presume different subjects, or at least different dimensions of the same subject. Coercive control is linked to the anonymous and impersonal construction of the pupil as an obedient subject, while the willing and voluntary subject is linked to the fabrication of an active, personal and responsible pupil as a future citizen.

Turning to the legitimising of the discipline discourse, two arguments can be highlighted. The first is a notion of the school as a small-scale society-a microcosm. The second is a clear distinction between normal and deviant. In referring to the school as a small-scale society, the boundaries between school and society are blurred. Indeed, the term society-school was sometimes used, suggesting a nearly symbiotic relation between the two. The blurring of boundaries was, however, not total; the two were held separate in some sense and school was generally portrayed as a subcategory of society. ${ }^{43}$ It is of some significance to note that this blending of terms such as school, society and state in several articles similar to the one by Wallerius seems to have had consequences for the way in which discipline and behaviour in school could be understood and legitimised. It made both the character and the scope of the school's task of disciplining plausible. Here one can discern one of the logics that supported physical punishment in the school. The blurring of boundaries made possible a link between society's right to punish criminals and the teacher's right to punish pupils: "When a child does not of its own accord profit from this [fine and all-round education], society is forced to take corrective measures" (my translation and italics) ${ }^{44}$ Here the writer replaces the term "school" with "society," implying that the two terms might be regarded as synonyms so that when pupils are disciplined by teachers, they are in an ultimate sense being disciplined by the whole society.

The blurring of the boundaries between school and society even made it possible to equate corporal punishment in the school with the state's punishment of criminals. Indeed, Wallerius drew a straight line between the school's task of character formation and the court's legal processes: "The offences of minors are no longer sub-

\footnotetext{
41 Ibid.

42 Ibid.

43 Ibid.

44 Ibid.
} 
mitted to ordinary courts of justice, but are nowadays investigated and dealt with by the school or the child welfare committee." 45 Thus, through analogy and the blurring of conceptual borders, the disciplinary practices of the school could be linked to a legal and penal discourse so that the corporal punishment of a bad pupil corresponds to the state's punishment of adult criminals. Wallerius completed his analogy by comparing the elementary schoolteacher's role with the hearing and judgement functions of a court: "But the public has little understanding of the exorbitant task of working with large classes made up of a mixed clientele. The educator has a tricky task. It is not easy to be at one and the same time: prosecutor, investigator, judge and bailiff' (my translation and italics). ${ }^{46}$

Another legitimisation of physical punishment in the school can be discerned in discussions of the differences between the normal and the deviant school pupil. The background to these distinctions was an agitated discussion about the dangers of corporal punishment to a child's mental health. Defenders of corporal punishment insisted that psychological accounts of behavioural problems did not apply to normal children. The number of references to mental health had increased, they claimed, because the diagnoses and treatment of deviant children had become the norm for educating all children. As educator Evald Fransson formulated the problem:

\begin{abstract}
Does the medical profession's way of looking at the matter have squatter's rights in the area of education for normally constituted children? That question becomes more and more inflamed and increasingly important to clear up. The psychiatrists, medical doctors et consortes who are now raising their voices, derive their experience from a child population which for one reason or another deviates from the norm. That implies a very real risk of error. One can compare them to military doctors, who often acquire warped knowledge and experience because they are always watching out for malingerers. And to the field of psychoanalysis, a profession that unquestionably has drawn its conclusions in absurdum because it generalizes its findings from an area of defective emotional life and applies them as the norm (my translation). ${ }^{47}$
\end{abstract}

In the same spirit, another writer worried that it had become necessary to apply "education of deviant children" even to "normal" children. The result was, he continued, that all essential dictates and bans had ceased to apply since they were intended for normal children and not deviants. ${ }^{48}$ Corporal punishment in the school could thus be legitimised by insisting that it was exercised only on normal children who needed straightening out, not on psychologically deviant pupils who required psychological care.

The above descriptions of discipline and behaviour were part of the fabrication of the desirable school pupil as an obedient and pliable subject whose physicality, rather than their intellect, will and emotions, was the focal point. The purpose of discipline in school was portrayed as upholding respect for law and order. At the same, it was stressed that to acquire these desirable qualities the pupils had to be

\footnotetext{
45 Ibid.

46 Ibid.

47 Folkskolan - Svensk Lärartidning (1947), 6-7.

48 Folkskolan - Svensk Lärartidning (1948), 8-9.
} 
active, participating and responsible. As I have argued above, these fabrications of the subject did not exclude one another; rather they existed side by side, depending on what discourse was invoked by the debaters.

\section{The progressive discourse: The self-reliant and democratic school pupil}

In 1951 the Swedish Teachers' Journal published an article by sociologist Joachim Israel entitled "Democracy and Authoritarian Education." ${ }^{49}$ This article had a considerable impact on the direction of discussions about the school's role in shaping the attitudes and behaviours of the pupils. ${ }^{50}$ Israel was a famous spokesperson for the concept of progressive education as it took shape during the 1940s and 1950s in Sweden. ${ }^{51}$ In collaboration with his wife, Mirjam Valentin-Israel, he had some years previously authored a pioneering work on child-rearing and education that broke radically with traditional educative ideals. The book had the telling title "There are no bad children!" (Det finns inga elaka barn!). The influence of Israel's thinking on the debate can be understood in part from the impact of this particular book, in which the emerging and progressive discourse was most clearly formulated. It will therefore be included in the analysis of progressive discourse.

Israel's article elevated the topic of discipline to a level of principle rather than discussing it at a practical classroom level. He categorically rejected all forms of disciplinary pedagogics, claiming that it had no place in a modern democratic society. To this end, he painted a picture of modern society that he contrasted with an older society, which he called "the strongly authoritarian, pre-democratic, agricultural society." ${ }^{2}$ Disciplinary pedagogics and corporal punishment were, in his understanding, linked with the antiquated, undemocratic society that Sweden should put behind it once and for all, whereas the new educational ideas were linked to the dawning democracy one should strive for. Against this background, a new image of the difficult school pupil was highlighted. The really problematic pupil was, according to Israel, not the bad child; rather, it was the obedient child. Concepts such as obedience and respect had become suspect within progressive discourse since they were associated with concepts that had no positive nuance whatsoever, concepts like "submission" and "fear." 3

All this might give the impression that the duty to obey was relegated to the category of the undesirable within progressive discourse, but this was not the case. Dictates and prohibitions as such were not rejected; rather, these concepts were charged with a new meaning. Thus, Israel did not call for a rejection of authority per se. Instead, he wanted to distinguish between two types of authority: an impartial authority and an irrational authority. The impartial authority was clearly linked to the progressive ideals that Israel himself represented, while the irrational authority was linked to the traditional ideals defended by Wallerius and those of like mind. This

49 Folkskolan-Svensk Lärartidning (1951), 2.

50 In the early fifties, Israel published numerous articles with similar content, both in newspapers and in various teachers' journals, see Qvarsebo (2006).

51 Swedish historian of education Gunnar Richardson mentions Israel as one of the most influential advocates of "permissive child-rearing" during this period, see Richardson (1983). See also Qvarsebo (2006).

52 Folkskolan - Svensk Lärartidning (1951), 2.

53 Ibid. 
categorising of two different types of authority made possible a discursive exclusion of disciplinary pedagogics and the inclusion of modern democratic pedagogics. Disciplinary pedagogics was dismissed as outmoded, authoritarian and ignorant; in short, it was relegated to history's garbage can. Meanwhile the new progressive ideas stood proudly alongside modernism, democracy and science. ${ }^{54}$

Two arguments used in legitimising this discourse were the significance of psychological research and the need for democratisation. In contrast to the disciplinarian discourse, Israel emphatically stated that disciplinary problems at school did not have their source in a child's innate bad character; rather, the social environment was at fault. ${ }^{55}$ When undesirable behaviour was no longer seen as an expression of bad character, children's accountability for their behaviour was also downplayed. Behaviour that had traditionally been categorised as bad was now fabricated as natural in the development of a child. This reconstruction of the causes of undesirable behaviour was supported by a number of scientific explanations of human behaviour, many rooted in psychology. Developmental psychology provided Israel and his fellow debaters with new ways of interpreting and describing children's behaviour. Certain behaviours that were unacceptable within the framework of the discipline discourse could now be described as wholly natural and typical for certain stages of development.

All parents should, in fact, become informed about what is typical for the various ages, and how physical and emotional development proceeds. Many problems and difficulties would then surely resolve themselves (my translation). ${ }^{56}$

If the age-typical behaviour did not disappear of its own accord, it was, according to Israel, due to "improper methods of child development." 57 The responsibility for the child's behaviour was thus settled upon those in charge of the child's development - the parents and teachers - rather than on the child itself. In the progressive discourse, moral judgement of behaviour was superseded by a scientific gaze wherein behaviour should be diagnosed and treated in a scientific manner. With developmental psychology as the factual base, the traditional emphasis on obedience could be observed in a new and critical light.

Instead [we find] an attempt to instil perfect obedience, with no heed to the child's natural needs as shaped by its stage of development, in order to turn out small wellbrought up, easily handled and obedient children. ${ }^{58}$

The legitimising psychological arguments were, however, not gleaned only from developmental psychology; psychoanalytical thinking may have been even more influential. From this perspective, terms such as "bad" were thought to be applied to children by parents and teachers because they lacked knowledge about the true

54 Ibid.

55 Joachim Israel and Mirjam Valentin-Israel, Det finns inga elaka barn! (Stockholm: Norstedt, 1946), 8-9.

56 Israel and Valentin-Israel (1946), 10.

57 Ibid., 12.

58 Ibid., 16. 
causes of the child's behaviour. A moralising gaze on the child was thus replaced with a therapeutic gaze. The duty of parents and teachers was to seek the real reasons for a child's behaviour in accordance with modern child psychology: "Here it is necessary to acquire knowledge that will allow one to fully see the child's problem and understand the cause and effect. Then parents too will understand that, in actual fact, there are no bad children!"59

References to society's need for democratisation were yet another way of legitimising the progressive discourse. Traditional ideas of education were described as irreconcilable with a democratic society: "For the greater the gap between the progress of democracy and an undemocratic authoritarian upbringing, the more often we will see people with the neuroses described above." 60 The impartial authority that was discursively linked to the progressive discourse was described as a determinative precondition for the establishment of a truly democratic society: "an impartial authority that suited a democratic society's demands on the rising generation." ${ }^{61}$ In contrast to how the school pupil was fabricated in the discipline discourse, Israel and his supporters emphasised qualities such as personality, self-will and emotions. The desirable school pupil of this discourse was an active, participating, and self-reliant subject. This pupil was assumed to develop and mature through an intimate relationship with parents and teachers, without disciplinary measures. The emphasis was on "establishing a trusting and comradely relationship" with children so they were able to "positively identify with [parents and teachers] and willingly accept [their elders'] dictates and bans." A traditional respect for authority should therefore be superseded by "mutual trust," and tough discipline should be superseded by "cooperation based on identification." Thus, the obligation to obey had its place within the progressive discourse, though it was expressed in terms of cooperation, identification, comradeship and so on. ${ }^{62}$ Even more pronouncedly than within the older discourses of citizenship, the goal of education was to shape a democratic citizen, a citizen capable of supporting a modern democratic society.

According to Israel, the entire repertoire of disciplinary measures reduced the individual's ability to become self-reliant, created anxiety, and imparted a life-long dependency on higher authority. The logic of governing here played on notions of reciprocity, trust and comradeship. It was a governing of the child and the pupil in the name of mutual trust and cooperation. The desirable school pupil was a child with needs of their own, who was self-reliant, capable of critical thinking and able to show initiative. As shown above, however, there was no less an obligation to obey authority, provided it was rational and therefore legitimate. The novelty of this fabrication of the subject was that the pupil should more consistently be governed on the basis of self-sufficiency and rationality, rather than on the basis of obedience and respect. Obedience was reconstructed and could now be portrayed as a willing cooperation with parents and teachers; in essence it was a teamwork based on a rational authority.

\footnotetext{
59 Ibid., 15.

60 Folkskolan - Svensk Lärartidning (1951), 2.

61 Ibid.

62 Ibid.
} 


\section{Overlapping discourses: The unruly and the psychologically defective pupil} In 1962, elementary school teacher Erik Sverud published an article with the title "Planning the school's character-shaping activities." ${ }^{63}$ The article was a contribution to the educational debate of the early 1960s. Since corporal punishment had been banned in 1958, the conditions for the discussion of behaviour and discipline had changed, making new discourses of behaviour and discipline possible. The main part of Sverud's article was devoted to a detailed proposal for annual planning days for teachers; a day he thought should be dedicated to the school's task of shaping the behaviours and attitudes of the pupils. Using the 1957 official report on the comprehensive school as a point of departure, Sverud elaborated on the meaning of the school's task of shaping the morals and behaviours of pupils. Parenthetically, one might mention here a shift in the talk about discipline and behaviour in the 1957 report in comparison with the reports from the 1946 Schools Commission. The task of the school in shaping the conduct of the pupils was now described in much more detail than before. ${ }^{64}$ This change was also reflected in Sverud's article. The 1957 report had described the components of good education as "education in sensibility, strengthening the will, ethics, industriousness, health, use of leisure time, development of individual and societal traits and preparedness for family life." Sverud agreed with this all of this, and using these attributes in a programmatic way, he elaborated on how the task of shaping the behaviour and conduct of pupils could be put in play in practical ways in a school.

These ideas of shaping behaviour and conduct can be viewed against the backdrop of a renewed debate on the school's means of discipline, a debate which had intensified after the ban on corporal punishment. Teachers' were asking about alternative means of discipline, now that physical punishment was no longer allowed. In line with this, Sverud suggested that every school should introduce annual planning days devoted to the topic of behaviour and conduct. To this end, he presented a rigorous programme that set aside three whole days for planning and discussion of conduct and discipline in school. The first day of planning should focus on the role of the teacher in shaping the attitudes and behaviour of the pupils. During this day, the teachers should work to find common goals for behaviour and conduct, including suitable ways of achieving these. Examples of topics of discussion were local rules and regulations and what kind of behaviour could be expected in school. The theme for the second day was campaigns for character improvement. Under this heading, Sverud proposed a number of character-shaping campaigns to be carried out each school year, such as "kindness and respect," "order and punctuality," "cleanliness and punctuality," "courtesy," "traffic rules" and "anti-tobacco, anti-sweets and anti-littering." ${ }^{65}$ The third day's theme was devoted to shaping the pupil's conduct through home and school cooperation. The proposed topic for this day was how one could form organised home and school alliances to promote good behaviour, and how organised contact with parents could be developed. The second and third

\footnotetext{
63 Folkskolan (1962), 7-8.

64 The tendency to regulate pupils' conduct in ever more detail, entailing more and more areas of governing, can be observed in a longer historical perspective. From the establishment of the Folkskolan (elementary school) in 1842, this progress is traceable in various school policy documents such as the many different editions of Folkskolestadgan (regulations for the elementary school).

65 Folkskolan (1962), 7-8.
} 
days should, in addition, be devoted to the importance of the pupil's participation in their own conduct. The teachers should also be encouraged to discuss how the pupils could own the rules and regulations of the school in personal ways, and how the teachers could help them to formulate specific rules. ${ }^{66}$

Sverud's enthusiasm for rigorous programmes of conduct was not unique. Similar programmes had been discussed in other articles appearing in the journal during the late fifties and early sixties. One example was the 1959 courtesy campaign, conducted in the schools in the town of Karlstad, which the editor of the journal thought should be imitated by schools everywhere. Director of Education Carl E. Carldén wrote an article about the Karlstad campaign and stressed the importance of "purposefully and methodically seeking to influence young people to acquire good habits and pursue an ethical lifestyle." ${ }^{.7}$ As with Sverud's planning days, this was a very detailed program for shaping the pupils' conduct and behaviour through goal-oriented and systematic activities. Carldén listed eight areas in which courtesy of conduct could be formed. One area was "polite greetings," which were discussed in great detail, down to instructions on when and how to greet friends and superiors. ${ }^{68}$ The program also incorporated detailed guidelines for things like "how to behave when you run an errand," "how to behave in a queue"and "how to behave in public places." 69

The image of the desirable school pupil that emerged in the debate of the sixties had both similarities and differences from the earlier debate. The overlap between the earlier discipline discourse and the progressive discourse is noticeable. The unruly pupil is discussed once more, which brings the older discipline discourse to mind, but now without reference to physical punishment. The psychologically defective pupil who, in accordance with the progressive discourse required medical and psychological expertise, is also discussed. The rationality of governing at play here is in harmony with this overlap of discourses and fabrications of the subject. On the one hand, the pupil should be controlled and subjected to programmes of conduct and behaviour that regulate behaviour down to the slightest movement and gesture. On the other hand, there is an emphasis on the importance of the pupil taking part in their own development of character and conduct, so that the desired behaviour becomes an internalised project for the pupil, carried out in cooperation with the teachers.

\section{The governing of the school pupil: A discursive shift or a merging of dis- courses?}

In relation to both the traditional historical works and some Foucauldian works on schooling and discipline, my analysis agrees with several of the interpretations of how discourses of behaviour and discipline, the rationalities of government, and the fabrications of the subject have been renegotiated and transformed from the postwar period onward. My study shows, however, that the history of the fabrication and governing of the school pupil during this period can be nuanced by more closely studying the interplay and borrowing between dominant discourses and how the school pupil was fabricated and governed in these discourses during this period. In

66 Ibid.

67 Folkskolan (1959), 5.

68 Ibid.

69 Ibid. 
my analysis, I have shown that several different, sometimes seemingly incompatible, discourses of behaviour and discipline were in play simultaneously during this period, making it difficult to talk about a radical shift from one discourse to another. Rather, my study points to a historical process where seemingly conflicting discourses could co-exist and overlap in such a way that none took precedence over the other. In other words, it is possible to question the claim that a traditional and moralistic discourse of discipline and behaviour, based on dictates, rules and governing from without, was replaced by a progressive discourse built upon psychology, freedom and self-regulation during this period..$^{70}$

The 1958 ban on corporal punishment in school made physical punishment impossible as means of correction and discipline, and this can certainly be described as quite a radical change in disciplinary methods. Nonetheless, the obedience theme of the disciplinary pedagogics and the logic of governing that emphasised detailed regulation of behaviour through rules and dictates is also present after 1958. In fact, the governing practices of discipline were refined and became even more detailed after 1958, even though the physical punishments disappeared. Pertaining to traditional historical works that have touched on discipline and behaviour, my analysis questions the humanistic narrative of progress and humanisation that some of these seem to take for granted..$^{71}$ Pertaining to some uses of a Foucauldian perspective on power, my analysis questions the idea that Foucault's main concepts of power such as sovereignty, pastoral power, discipline, bio-power and governmentality should be understood as forms of power that succeed one another in chronological order. ${ }^{72}$

The progressive discourse that grew in influence after 1945 was indeed important for the fabrication of a self-reliant subject who was in many ways different from the obedient subject fabricated within the older discipline discourse. This self-reliant subject was associated with a new rationality of government where participation, comradeship, and trust were in the foreground. My analysis shows, however, that there was also plenty of room within the discipline discourse for a participatory and self-reflexive subject who was expected to take responsibility for their own behaviour and actively take part in their own governing. This subject emerges most clearly in the discussion of training for democratic citizenship. Here one can observe a logic of governing that presumes a rational subject able to understand and assimilate instructions and reflect on their own behaviour. The modern language of psychology, which increasingly permeated the discussion of behaviour and conduct in the articles after 1945, need therefore not necessarily be regarded as an expression of a radical shift of governing rationalities. It can instead be viewed as a continuation and radicalisation of notions of the pupil, behaviour and conduct that were already in play in the earlier citizenship discourse. The process can perhaps more properly be described as a discursive struggle in which different subjects and rationalities of government could be activated within several discourses at the same time.

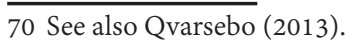

71 For Swedish influentual school historical works of this type, see for instance Richardson (1983) and Åke Isling, Kampen för och emot en demokratisk skola - del 1: Samhällsstruktur och skolorganisation (Stockholm: Sober, 1980); Åke Isling, Kampen för och mot en demokratisk skola. 2, Det pedagogiska arvet (Stockholm: Sober, 1988).

72 For a critique of using Foucault's analytics of power in this chronological way see Magnus Hörnqvist, En annan Foucault: Maktens problematik (Stockholm: Carlssons Bokförlag, 2012). 


\section{References}

Axelsson, Thom. Rätt elev i rätt klass: Skola, begåvning och styrning 1910-1950. Linköping: Linköpings Universitet, 2007.

Axelsson, Thom and Jonas Qvarsebo. Maktens skepnader och effekter: Maktanalys $i$ Foucaults anda. Lund: Studentlitteratur, 2017.

Ball, Stephen J. Foucault, Power and Education. New York, London: Routledge, 2013.

Baker, Bernadette. "Childhood-as-rescue in the emergence and spread of the U.S. public school." In Foucault's Challenge: Discourse, Knowledge and Power in Education, edited by Thomas Popkewitz and Marie Brennan. New York: New York Teachers College Press, 1998.

Besley, Tina and Michael A. Peters. Subjectivity and Truth: Foucault, Education and the Culture of Self. New York: Peter Lang, 2007.

Börjesson, Bengt. "Det ideologiskt omstridda barnet." In Seendet och seendets villkor. En bok om barns och ungas välfärd, edited by Lars Dahlgren and Kenneth Hultqvist. Stockholm: HLS, 1995.

Cruikshank, Barbara. The Will to Empower: Democratic Citizens and other Subjects. New York: Cornell University Press, 1999.

Dean, Mitchell. Governmentality: Power and Rule in Modern Society. Thousand Oaks: SAGE, 2009.

Dreyfus, Hubert L. and Paul Rabinow. Michel Foucault: Beyond Structuralism and Hermeneutics. Chicago: University of Chicago Press, 1982.

Edgren, Henrik. "Folkskolan och grundskolan." In Utbildningshistoria, edited by Esbjörn Larsson and Johannes Westberg. Lund: Studentlitteratur, 2015.

Foucault, Michel. The Archaeology of Knowledge and the Discourse on Language. New York: Pantheon Books, 1972.

Foucault, Michel. Discipline and Punish: The Birth of the Prison. London: Penguin, 1978.

Foucault, Michel. The History of Sexuality: An Introduction. Vol I. New York: Vintage Books, 1978.

Foucault, Michel. "Prisons et asiles dans le mécanisme du pouvoir." In Dits et Ecrits, t. II. Paris: Gallimard, [1974] 1994.

Foucault, Michel. "Governmentality." In The Foucault Effect: Studies in Governmentality, edited by Graham Burchell, Colin Gordon and Peter Miller. Chicago: University of Chicago Press, 1991.

Foucault, Michel. "The Political Function of the Intellectual." Radical Philosophy 17 (1977), 113-14.

Folkskolan - Svensk lärartidning: Tidskrift för Federationen Sveriges allmänna folkskollärarförening, Sveriges allmänna folkskollärarförening. Göteborg: Folkskolan - Svensk lärartidning, 1947.

Folkskolan: Tidskrift för Federationen Sveriges allmänna folkskollärarförening, Sveriges allmänna folkskollärarförening. Stockholm: Federationen Sveriges allmänna folkskollärarförening, 1959-1962.

Folkskolestadgan och andra författningar rörande det obligatoriska skolväsendet, edited by Frenne Frankman. Lund: H. Olsson, 1959.

Hendrick, Harry. Children, Childhood and English Society 1880-1990. New Studies in Economic and Social History. Cambridge: Cambridge University Press, 1997. 
Hultqvist, Kenneth. Förskolebarnet: En konstruktion för gemenskapen och den individuella frigörelsen. En nutidshistorisk studie om makt och kunskap $i$ bilden av barnet $i$ statliga utredningar om förskolan. Stockholm: Symposium, 1990.

Hultqvist, Kenneth and Gunilla Dahlberg, eds. Governing the Child in the New Millennium. New York: RoutledgeFalmer, 2001.

Hunter, Ian. Rethinking the School: Subjectivity, Bureaucracy, Criticism. Sydney: Allen \& Unwin, 1994.

Husén, Torsten and Nils-Eric Svensson. Elever - lärare - föräldrar: En studie av skolans uppfostrings- och disciplinproblem. Stockholm: Almqvist \& Wiksell, 1959.

Hörnqvist, Magnus. En annan Foucault: Maktens problematik. Stockholm: Carlssons Bokförlag. 2012.

Isling, Åke. Kampen för och emot en demokratisk skola - del 1: Samhällsstruktur och skolorganisation. Stockholm: Sober, 1980.

Isling, Åke. Kampen för och mot en demokratisk skola. 2, Det pedagogiska arvet. Stockholm: Sober, 1988.

Israel, Joachim and Mirjam Valentin-Israel. Det finns inga elaka barn! Stockholm: Norstedt, 1946.

Landahl, Joakim. Auktoritet och ansvar: Lärares fostrans- och omsorgsarbete i historisk belysning. Stockholm: Stockholms Universitet, 2006.

Lindgren, Sven-Åke. "Michel Foucault och sanningens historia." In Moderna samhällsteorier, edited by Per Månsson. Stockholm: Rabén Prisma, 1995.

Marklund, Sixten. Skolsverige 1950-1975. Volym 4: Differentieringsfrågan. Stockholm: Liber/utbildningsförlag, 1985.

Mills, Sara. Discourse. London: Routledge, 1997.

Piro, Joseph M. "Foucault and the architecture of surveillance: Creating regimes of power in schools, shrines, and society." Educational Studies 44, no. 1 (2008), 33-46.

Popkewitz, Thomas. "The sociology of education as the history of the present: Fabrication, difference and abjection." Discourse: Studies in the Cultural Politics of Education 34, no. 3 (2013), 439-56.

Qvarsebo, Jonas. Skolbarnets fostran: Enhetsskolan, agan och politiken om barnet 1946-1962. Linköping: Linköpings universitet, 2006.

Qvarsebo, Jonas. "Det önskvärda skolbarnet: Diskurser om barn och fostran i svensk Lärartidning 1946-1962." In Normalitetens förhandling och förvandling: En antologi om barn, skola och föräldraskap edited by Judith Lind. Lund: Symposion, 2006.

Qvarsebo, Jonas. “Grundskolereformen och talet om differentieringen: Differentieringsfrågan och konstruktionen av barns och ungas olikheter." In Historien, barnen och barndomarna: Vad är problemet?, edited by Judith Lind, et al. Linköping: Linköpings Universitet, 2009.

Qvarsebo, Jonas. "Swedish progressive school politics and the disciplinary regime of the school, 1946-1962: A genealogical perspective." Paedagogica Historica 49, no. 2 (2013), 217-35.

Richardson, Gunnar. Drömmen om en ny skola: Ideer och realiteter i svensk skolpolitik 1945-1950. Stockholm: Liber Förlag, 1983.

Rose, Nikolas. The Psychological Complex: Psychology, Politics and Society in England 1869-1939. London: Routledge, 1985. 
Rose, Nikolas. Governing the Soul: The Shaping of the Private Self. London: Free Association Books, 1999.

SOU 1948:27. 1946 års skolkommissions betänkande med förslag till riktlinjer för det svenska skolväsendets utveckling. Stockholm, 1948.

Svensk lärartidning: Organ för Sveriges allmänna folkskollärarförening. Sveriges allmänna folkskollärarförening. Stockholm: Svensk lärartidning, 1946.

Turmel, André. A Historical Sociology of Childhood: Developmental Thinking, Categorization and Graphic Visualization. Cambridge: Cambridge University Press 2008.

Widén, Martin. "Skoltidningar och tidskrifter." In Viktor Fredriksson ed., Svenska folkskolans historia. Sjätte delen - Skolutvecklingen 1942-1962: Grundskolans förhistoria. Stockholm: Stiftelsen för förvaltningen av Sveriges Allmänna Folkskollärarföreningstillgångar, 1971. 